\title{
EFEK ANTIMIKROBA SEDIAAN SALEP KULIT BERBAHAN AKTIF EKSTRAK ETIL ASETAT DAUN SUNGKAI (Peronema Canencens Jack.) TERHADAP BAKTERI PATOGEN PENGINFEKSI LUKA BAKAR
}

\author{
Arsyik Ibrahim ${ }^{1}$, Islamudin Ahmad ${ }^{2}$, Angga Cipta Narsa ${ }^{3}$, Yurika Sastyarina ${ }^{4}$ \\ ${ }^{1}$ Bagian Biologi-Mikrobiologi Farmasi, UP. Fakultas Farmasi Universitas Mulawarman, Samarinda \\ ${ }^{2}$ Bagian Bahan Alam Farmasi, UP. Fakultas Farmasi Universitas Mulawarman, Samarinda \\ ${ }^{3}$ Bagian Teknologi Farmasi, UP. Fakultas Farmasi Universitas Mulawarman, Samarinda \\ ${ }^{4}$ Bagian Farmakologi UP. Fakultas Farmasi Universitas Mulawarman, Samarinda
}

\begin{abstract}
Research on the effects of skin ointment dosage active ingredient ethyl acetate leaf extract Sungkai (Peronema canencens Jack.) has be done burns infection against pathogens bacteria. This study aims to determine the effective concentration of the ethyl acetate extract antimicrobial in skin ointment preparations against pathogens skin burns infection. Test material obtained by fractionation of the methanol extract of leaves Sungkai, further formulated into an ointment base, was tested to determine the effective concentration of activity. The results obtained by the concentration of effective skin ointment preparation with the active ingredient ethyl acetate leaf extract Sungkai is 4\% for gram-positive bacteria: $B$. subtilis and S. aureus, dankonsentrasi $2 \%$ for gram-negative bacteria: P. aeruginosa and Str. mutans.
\end{abstract}

Key words: P. canencens Jack, Formulation, Antimicrobials, B. subtilis, S. aureus, P. aeruginosa, Str. Mutans

\begin{abstract}
ABSTRAK
Telah dilakukan penelitian efek sediaan salep kulit berbahan aktif ekstrak etil asetat daun sungkai (Peronema canencens Jack.) terhadap bakteri patogen penginfeksi luka bakar. Penelitian ini bertujuan mengetahui konsentrasi efektif antimikroba ekstrak etil asetat dalam sediaan salep kulit terhadap bakteri patogen penginfeksi luka bakar. Bahan uji diperoleh dengan fraksinasi ekstrak metanol daun sungkai, selanjutnya formulasikan ke dalam basis salep, diuji aktivitasnya untuk menentukan konsentrasi efektif. Hasil penelitian diperoleh konsentrasi efektif sediaan salep kulit dengan bahan aktif ekstrak etil asetat daun Sungkai adalah $4 \%$ untuk bakteri gram positif: B. subtilis dan S. aureus, dankonsentrasi $2 \%$ untuk bakteri gram negatif: $P$. aeruginosa dan Str. Mutans.
\end{abstract}

Kata kunci : P. canencens Jack, Formulasi, Antimikroba, B. subtilis, S. aureus, $P$. aeruginosa, Str. mutans. 


\section{PENDAHULUAN}

Ekstrak metanol daun Sungkai memiliki aktivitas antimikroba terhadap bakteri $B$. subtilis, S. aureus, Str. mutans pada konsentrasi minimal 1\% (Ibrahim, A., dkk. 2012). Berdasarkan aktivitas ekstrak metanol daun sungkai terhadap beberap bakteri patogen khususnya bakteri penginfeksi luka, maka perlu dilakukan perluasan penelitian dengan melakukan pengujian dan penentuan fraksi-fraksi ekstrak metanol daun Sungkai yang memiliki aktifitas antimikroba terhadap bakteri patogen penginfeksi luka bakar selanjutnya dikembangkan dalam bentuk sediaan farmasi untuk menigkatkan penggunaannya.

Salah satu sediaan farmasi yang dapat memudahkan dalam penggunaannya ialah sediaan salep, dipilih sediaan salep karena merupakan sediaan dengan konsistensi yang cocok untuk terapi penyakit kulit yang disebabkan oleh bakteri. Salep terdiri dari bahan obat yang terlarut ataupun terdispersi di dalam basis atau basis salep ebagai pembawa zat aktif. Basis salep yang digunakan dalam sebuah formulasi obat arus bersifat innert dengan kata lain tidak merusak ataupun mengurangi efek terapi dari obat yang dikandungnya (Anief, 2007).

Berdasarkan hal tersebut diperlukan penelitian lebih lanjut aktifitas antimikroba ekstrak daun Sungkai yang dibuat dalam sediaan salep untuk mengetahui konsentrasi efektif antimikroba ekstrak etil asetat dalam sediaan salep terhadap antimikroba penginfeksi luka bakar.

\section{METODE}

Tempat penelitian.

Penelitian ini dilakukan di Laboratorium Kimia Bahan Alam Farmasi, Laboratorium Teknologi Farmasi dan Laboratorium Biologi Farmasi Farkultas Farmasi Universitas Mulawarman. Sampel penelitian adalah ekstrak fraksi etil asetat daun $P$. canencens Jack.

\section{Bahan penelitian}

Pelarut organik $n$-heksan, etil asetat dan alkohol 98\% teknis, medium uji Nutrien Agar (NA), tween 80, $\mathrm{NaCl}$ fisiologis 0,9\%, Tween 80, Parafin liquidum, Alfa tokoferol, Cera alba, dan Vaselin album. Biakan mikroba anatara lain strain Basillus subtilis, Staphylococcus aureus, Pseudomonas aeruginosa dan Streptococcus mutans.

\section{Alat-alat yang digunakan.}

Corong pisah, seperangkat alat evaporator, seperangkat alat sterilisasi (oven, auto clove), inkubator, alat-alat gelas, mikro pipet, cawan Petri, pipet mikro, timbangan analitik, Lumpang dan stamper, botol salep, vortex mixer.

\section{Pembuatan Sediaan Salep.}

Formula sediaan salep ekstrak etil asetat yang digunakan sebagai basis salep kulit seperti yang tertera pada Tabel 1 .

\section{Pengujian Aktivitas Antimikroba Ekstrak dan Sediaan Salep.}

Fraksi etil asetat daun $P$. canencens kering diuji aktivitasnya terhadap beberapa mikroba uji dengan menggunakan medium Nutrien Agar, metode dilusi padat 
menggunakan kertas cakram diameter 7 mm, medium - medium uji selanjutnya diinkubasi suhu $37^{\circ} \mathrm{C}$ selama 24 jam dalam inkubator. Pengamatan Daya Bunuh ekstrak berdasarkan terbentuknya zona bening/transparan disekeliling kertas cakram. (Djide, 2008). Pengujian sediaan salep mengandung ekstrak etil asetat pengerjaannya sama dengan pengujian aktifitas ekstrak etil asetat.

Tabel 1. Formula sediaan salep berbahan aktif ekstrak fraksi etil asetat

\begin{tabular}{lccc}
\hline \multicolumn{1}{c}{ Bahan } & F1 & F2 & F3 \\
\hline Ekstrak etil asetat & $1 \%$ & $2 \%$ & $3 \%$ \\
Parafin Liquidum & $20 \%$ & $20 \%$ & $20 \%$ \\
Cera alba & $4 \%$ & $4 \%$ & $4 \%$ \\
Alfa tokoferol & $0,05 \%$ & $0,05 \%$ & $0,05 \%$ \\
Vaselin Album & $100 \%$ & $100 \%$ & $100 \%$ \\
\hline
\end{tabular}

\section{Analisis Hasil.}

Data akhir hasil penelitian penentuan konsentrasi efektif sediaan salep berbahan aktif fraksi ekstrak etil asetat dianalisis dengan menggunakan analisis deskriptif kuantitatif Anova satu arah.

\section{HASIL DAN PEMBAHASAN}

\section{a) Aktivitas Antimikroba Salep Ekstrak Etil Asetat Daun Sungkai}

Hasil pengujian aktivitas ekstrak fraksi etil asetat dihasilkan bahwa konsentrasi minimal yang memberikan aktivitas minimal daya bunuh adalah konsentrasi $4 \%$ terhadap 4 macam bakteri uji yaitu bakteri B. subtilis, S. aureus, Str. mutans dan P. aeruginosa, sedangkan untuk bakteri $S$. Epidermidis dan khamir M. Purpurea aktivitas ekstrak kurang baik. Berdasarkan hasil tersebut selanjutnya dilakukan formulasi ekstrak ke dalam basis salep terbaik yaitu basis yang mengandung Cera alba $4 \%$ dimana basis ini dipilih berdasarkan hasil pengujian dengan kestabilan paling baik diantara variasi konsentrasi cera alba yang lain. Konsentrasi ekstrak yang diformulasikan ke dalam basis menggunakan 3 macam variasi konsentrasi yaitu $4 \%, 2 \%$ dan $1 \%$, dan bakteri uji yang digunakan terdiri dari 4 macam bakteri uji yaitu $B$. subtilis, $S$. aureus merupakan bakteri golongan gram positif, dan Str. mutans dan P. aeruginosa digolongkan dalam golongan gram negatif. Hasil pengujian aktivitas antimikroba sediaan salep mengandung ekstrak etil asetat berdasarkan daya bunuh ( $\mathrm{mm}$ ) dapat dilihat pada Tabel 2 dan Gambar 1, 2 dan 3 .

Tabel 2. Diameter hasil uji aktivitas sediaan salep fraksi etil asetat daun Sungkai terhadap bakteri uji dengan kontrol negatif aquadestilta

\begin{tabular}{lccccc}
\hline \multirow{2}{*}{ Jenis Bakteri } & Perlakuan & \multicolumn{2}{c}{ Konsentrasi ekstrak fraksi daun Sungkai (\%) } & Kontrol (-) \\
\cline { 2 - 4 } & Rata-rata & $4 \%$ & $2 \%$ & $1 \%$ & Aquadestilata \\
\hline Bacillus subtilis & $\mathrm{r} \sum$ & 4.96 & 4.00 & 0.00 & 0.00 \\
S. aureus & $\mathrm{r} \sum$ & 3.48 & 2.45 & 0.20 & 0.00 \\
P. aeruginosa & $\mathrm{r} \sum$ & 1.74 & 2.37 & 0.00 & 0.00 \\
S. mutans & $\mathrm{r} \sum$ & 4.86 & 5.07 & 0.00 & 0.00 \\
\hline
\end{tabular}


Aktifitas Antimikroba Ekstrak Fraksi n-Heksan Daun Sungkai (Peronema canescens. JACK) Terhadap Beberapa Bakteri Dengan Metode KLT-Bioautografi

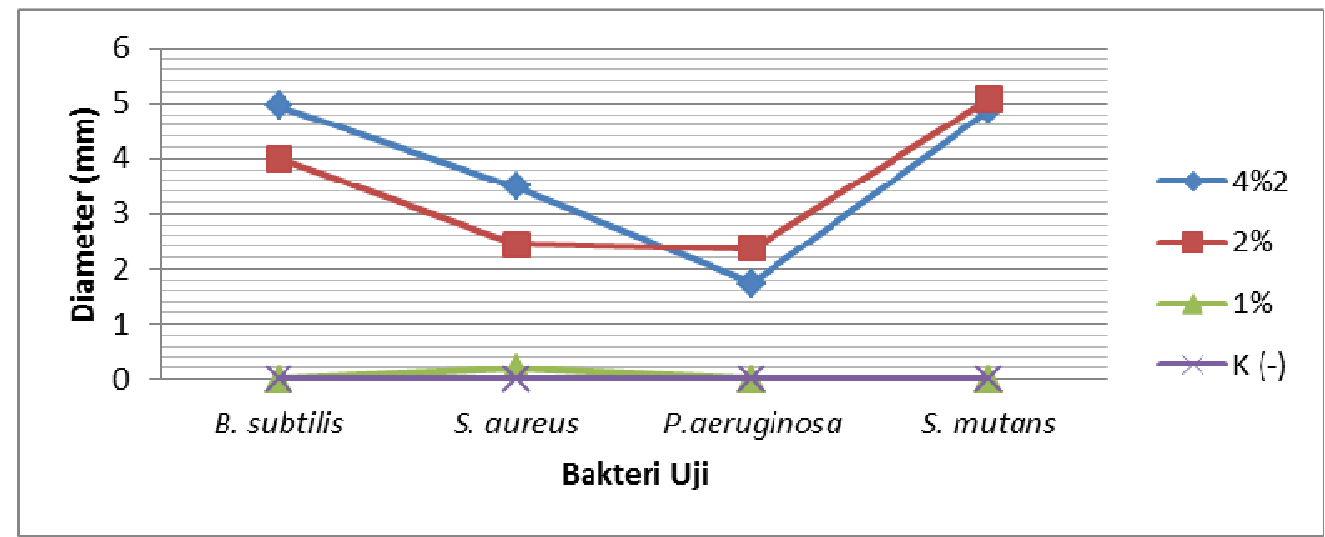

Gambar 1. Grafik hasil uji aktivitas sediaan salep mengandung ekstrak etil asetat daun Sungkai terhadap bakteri uji

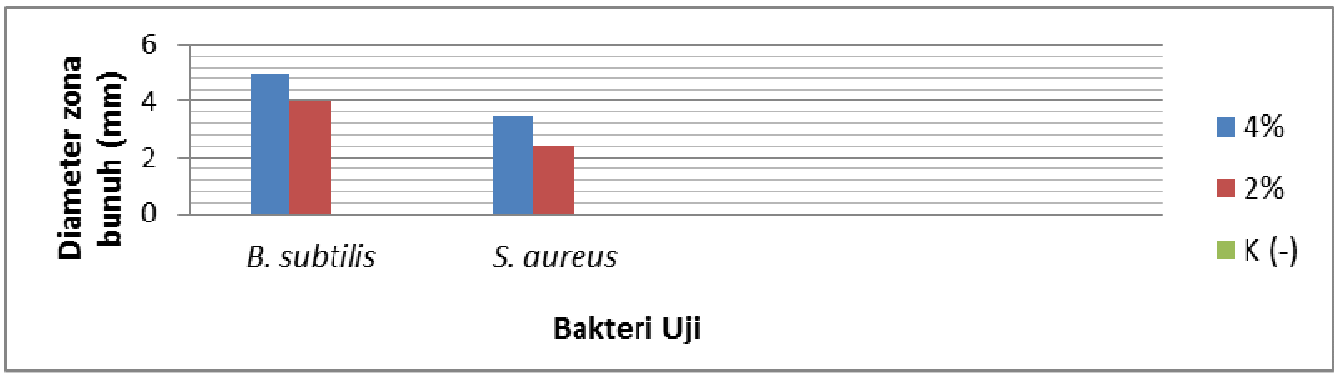

Gambar 2. Grafik potensi aktivitas sediaan salep fraksi etil asetat daun Sungkai terhadap bakteri gram positif dibandingkan dengan kontrol negatif aquadestilata

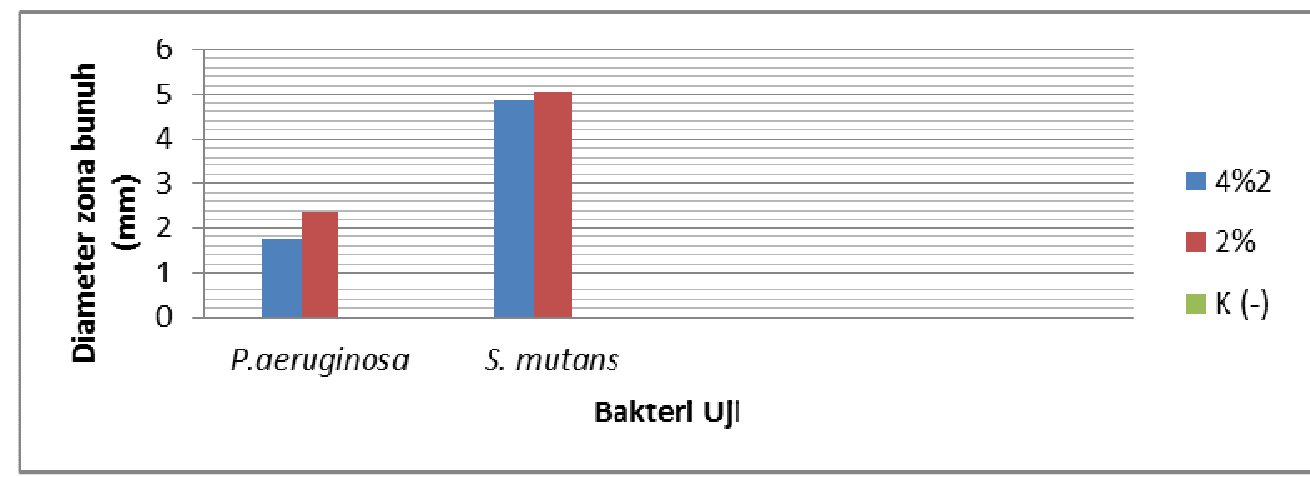

Gambar 3. Grafik potensi aktivitas sediaan salep fraksi etil asetat daun Sungkai terhadap bakteri gram negatif dibandingkan dengan kontrol negatif aquadestilata

Data dalam Tabel 5, Gambar 1 menunjukan aktivitas daya bunuh sediaan salep mengandung ekstrak etil asetat $1 \%$, $2 \%$ dan $4 \%$ terhadap bakteri B. subtilis, $S$. aureus, $P$. aeruginosa dan Str. mutans, dan Gambar 2 menunjukan aktivitas daya bunuh sediaan salep mengandung ekstrak etil asetat terhadap bakteri gram positif $B$. subtilis dan $S$. aureus. Gambar 3 menunjukan aktivitas daya bunuh sediaan salep terhadap bakteri gram negatif $P$. aeruginosa dan Str. mutans. Aktivitas antibakteri sediaan salep terhadap bakteri $B$. subtilis dan $S$. aurues secara visual terbaik pada sediaan salep dengan konsentrasi ekstrak etil asetat $4 \%$, 
sedangkan untuk bakteri $P$. aeruginosa dan Str. mutans terbaik pada sediaan dengan konsentrasi ekstrak etil asetat $2 \%$.

\section{b) Konsentrasi efektif sediaan salep sebagai antimikroba}

Penentuan konsentrasi efektif terhadap golongan bakteri gram positif dan gram negatif dari masing-masing konsentrasi ekstrak etil asetat sebagai bahan aktif sediaan salep dilakukan berdasarkan uji pengaruh (uji ANOVA). Penentuan konsentrasi efektif berdasarkan hasil lanjutan statistik lanjutan menggunakan Uji Beda Nyata Terkecil (BNT). Hasil uji lanjutan BNT dapat dilihat pada Tabel 3 dan Tabel 4.

Tabel 3.Hasil uji BNT sediaan salep berbahan aktif ekstrak etil asetat terhadap bakteri B. subtilis dan S. aureus

\begin{tabular}{cccccc}
\hline \multirow{2}{*}{ Bakteri Uji } & Konsentrasi & $\begin{array}{c}\text { Rerata Diameter Zona Bening } \\
(\mathbf{m m})\end{array}$ & \multicolumn{3}{c}{ Beda Dengan } \\
\cline { 4 - 6 } & $1 \%$ & 0 & $\mathbf{1 \%}$ & $\mathbf{2 \%}$ & $\mathbf{4 \%}$ \\
\hline \multirow{3}{*}{ B. subtilis } & $2 \%$ & $\mathbf{4 . 0 0}$ & $4,00^{* *}$ & - & \\
& $4 \%$ & $\mathbf{4 . 9 6}$ & $4,96^{* *}$ & $0,96^{* *}$ & - \\
\multirow{2}{*}{ S. aureus } & $1 \%$ & $\mathbf{0 . 2 0}$ & - & & \\
& $2 \%$ & $\mathbf{2 . 4 6}$ & $2,26^{* *}$ & - \\
& $4 \%$ & $\mathbf{3 . 4 8}$ & $3,28^{* *}$ & $1,02^{* *}$ \\
\hline \multicolumn{2}{c}{ Nilai BNT } & $\mathbf{5 \%}$ & & $\mathbf{0 , 2 9}$ & \\
\end{tabular}

Tabel 4. Hasil uji BNT sediaan salep berbahan aktif ekstrak etil asetat terhadap bakteri P. aeruginosa dan Str. mutans

\begin{tabular}{cccccc}
\hline \multirow{2}{*}{ Bakteri Uji } & \multirow{2}{*}{ Konsentrasi } & $\begin{array}{c}\text { Rerata Diameter Zona Bening } \\
(\mathbf{m m})\end{array}$ & \multicolumn{3}{c}{ Beda Dengan } \\
\cline { 3 - 6 } & & 0 & $\mathbf{1 \%}$ & $\mathbf{2 \%}$ & $\mathbf{4 \%}$ \\
\hline \multirow{3}{*}{ P.aerugunisa } & $1 \%$ & $\mathbf{4 . 8 7}$ & $4,87^{* *}$ & - & \\
& $4 \%$ & $\mathbf{5 . 0 8}$ & $5,08^{* *}$ & 0,21 & - \\
\multirow{3}{*}{ Str. mutans } & $2 \%$ & 0 & - & & \\
& $1 \%$ & $\mathbf{1 . 7 4}$ & $1,74^{* *}$ & - \\
& $4 \%$ & $\mathbf{2 . 3 7}$ & $2,37^{* *}$ & $0,63^{* *}$ \\
\hline \multirow{2}{*}{ Nilai BNT } & $\mathbf{5 \%}$ & $\mathbf{5 \%}$ & $\mathbf{0 , 4 0}$ & \\
& & $\mathbf{1 \%}$ & $\mathbf{0 , 5 6}$ & \\
\hline
\end{tabular}

Keterangan:
$(*) \quad=$ Signifikan
$(* *) \quad=$ Sangat Signifikan

Data hasil uji lanjutan BNT untuk golongan bakteri gram positif menunjukan bahwa konsentrasi ekstrak etil asetat dalam sediaan salep luka bakar yang memberikan aktifitas terbaik/efektif adalah konsentrasi $4 \%$ yang memberikan pengaruh sangat signifikan/sangat berbeda nyata $(\mathrm{FT}<\mathrm{FH})$ dalam memberikan aktifitas antimikroba dibandingkan dengan konsentrasi uji lainnya.

Data hasil uji lanjutan BNT untuk golongan bakteri gram negatif menunjukan 
bahwa konsentrasi ekstrak etil asetat dalam sediaan salep luka bakar yang memberikan aktifitas terbaik/efektif adalah konsentrasi $2 \%$ yang memberikan pengaruh sangat signifikan/sangat berbeda nyata $(\mathrm{FT}<\mathrm{FH})$ dalam memberikan aktifitas antimikroba dibandingkan dengan konsentrasi uji lainnya.

Hasil analisis statistik terhadap dua golongan bakteri uji menunjukkan hasil yang berbeda, perbedaan aktivitas ini diduga disebabkan perbedaan komposisi dinding sel antara bakteri golongan gram positif dan gram negatif. Penyusun dinding sel bakteri golongan gram positif yaitu $B$. subtilis dan $S$. aurues mengandung lapisan mukopeptida/peptidoglikan yang tebal $(40 \%-50 \%)$ dari berat tubuh bakteri sehingga membutuhkan konsentrasi ekstrak yang lebih besar untuk memberikan aktifitas maksimal, sedangkan bakteri $P$. aeruginosa dan Str. mutans termasuk dalam kelompok bakteri gram negatif dengan komposisi dinding selnya mengandung lapisan lemak $(20 \%)$ dengan lapisan peptidoglikan yang tipis (5-20\%), dari berat tubuh bakteri sehingga dengan konsentrasi ekstrak lebih kecil telah mampu memberikan aktifitas daya bunuh optimal.

Kemampuan ekstrak etil asetat membunuh mikroba uji diduga oleh aktivitas metabolit sekunder yang terdapat dalam ekstrak etil asetat daun Sungkai. Golongan metabolit sekunder yang terdapat dalam ekstrak metanol daun Sungkai adalah golongan polifenol yaitu flavonoid dan tanin (Ibrahim, A., dkk., 2012) sedangkan metabolit sekunder yang terdapat dalam fraksi ekstrak etil asetat adalah golongan flavonoid dan tannin ( Hadi.I., 2011). Mekanisme antibakteri metabolit sekunder golongan senyawa polifenol merupakan kelompok terbesar dalam tumbuhan salah satunya adalah tanin yang memiliki aktivitas antibakteri, secara garis besar mekanisme yang diperkirakan yaitu toksisitas golongan senyawa polifenol dapat merusak membran sel bakteri. Mekanisme antibakteri golongan flavonoid dengan cara membentuk senyawa kompleks terhadap protein ekstraseluler yang mengganggu integritas membran sel bakteri. Menurut (Dwidjoseputro, 2005) flavanoid merupakan senyawa fenol, sementara senyawa fenol dapat bersifat koagulator protein.

Menurut (Ajizah, 2004) tanin merupakan kelompok senyawa polifenol yang memiliki aktifitas antibakteri, mekanisme kerja tanin sebagai antibakteri diduga dapat mengkerutkan dinding sel atau membran sel sehingga mengganggu permeabilitas sel itu sendiri, akibat terganggunya permeabilitas, sel tidak dapat melakukan aktivitas hidup sehingga pertumbuhannya terhambat atau bahkan mati. Tanin juga mempunyai daya antibakteri dengan cara mempresipitasi protein, karena diduga tanin mempunyai efek yang sama dengan senyawa fenolik. Efek antibakteri tanin antara lain melalui reaksi dengan membran sel, inaktivasi enzim, dan destruksi atau inaktivasi fungsi materi genetik. (Akiyama, dkk., 2001)

Selain itu kemampuan senyawa antibakteri dalam menghambat pertumbuhan bakteri dipengaruhi oleh kestabilan terhadap protein, lipid, garam dan tingkat keasaman $(\mathrm{pH})$ dalam medium pertumbuhan. (Djide, 2008)

\section{KESIMPULAN}

Konsentrasi efektif sediaan salep berbahan aktif ekstrak etil asetat daun Sungkai adalah $4 \%$ untuk bakteri gram positif : $B$. subtilis dan S. aureus, dankonsentrasi $2 \%$ untuk bakteri gram negatif : $P$. aeruginosa dan Str. mutans. 


\section{UCAPAN TERIMA KASIH}

Ucapan terima kasih kepada Universitas Mulawarman melalui Lembaga Penelitian Unmul yang telah memberikan dana dan menerima proposal penelitian ini sebagai salah satu yang dinyatakan lolos seleksi penelitian Hibah Bersaing tahun 2013, kepada ketua UP. Fakultas Farmasi Unmul dan kepala Laboratorium dan laboran Kimia Bahan Alam Farmasi, Teknologi Farmasi dan Biologi- Mikrobiologi UP. Fakultas Farmasi Unmul yang telah memberikan izin menggunakan laboratorium dan membantu penelitian ini.

\section{DAFTAR PUSTAKA}

1. Ajizah, A. 2004. Sensitivitas Salmonella Typhimurium terhadap Ekstrak Daun Psidium guajava L. Bioscientiae, Vol.1, No.1 : 31-8.

2. Akiyama, H., Fuji., Yamasaki., dkk. 2001. Antibacterial Action of Several
Tannins Agains Staphylococcus aureus.,Journal of Antimicrobia Cahemotherapy. Vol. 48 : 487-91.

3. Anief, M. 2007. Farmasetika. Gadjah Mada University Press, Yogyakarta.

4. Djide, N, \& Sartini. 2008. Analisis Mikrrobiologi Farmasi. Universitas Hasanuddin; Makassar

5. Dwidjoseputro. 2005. Dasar-Dasar Mikrobiologi. Djambaran; Jakarta.

6. Hadi, I. 2011. Identifikasi Metabolit Sekunder dan Aktivitas Antibakteri Ekstrak Daun Sungkai (P. canescens. Jack). Skripsi Sarjana. Samarinda : Fakultas Farmasi Universitas Mulawarman. 45-46.

7. Ibrahim., A., Kuncoro., H. 2012. Identifikasi Metabolit Sekunder dan Aktivitas Antibakteri Ekstrak Daun Sungkai (Peronema canescens Jack.) terhadap Beberapa Bakteri Patogen. Penelitian Hibah Dosen Pemula. Samarinda. 